\title{
The principal-agent problem and transport energy use: Case study of company lease cars in the Netherlands
}

\author{
Wina Graus ${ }^{a}$, Ernst Worrell ${ }^{\mathrm{a}, \mathrm{b}, *}$ \\ ${ }^{a}$ Ecofys Netherlands, PO Box 8408, 3503 RK Utrecht, The Netherlands \\ b Copernicus Institute, Utrecht University, Heidelberglaan 2, 3584 CS Utrecht, The Netherlands
}

\section{A R T I C L E I N F O}

\section{Article history:}

Received 25 March 2008

Accepted 1 July 2008

Available online 13 August 2008

\section{Keywords:}

Barrier

Energy efficiency

Transport

\begin{abstract}
A B S T R A C T
Barriers exist for improvement of energy efficiency, of which the principal-agent problem is considered an important one. The principal-agent problem is a potential barrier for energy policies based on economic instruments, as the decision maker may be partially insulated from the price signal given by such policies. We estimate the size and the impact of the principal-agent problem for cars provided by companies as a benefit to employees in the Netherlands. Of all passenger cars in the Netherlands, $11 \%$ is classified as company cars, which consume $21 \%$ of the total energy consumption by passenger cars. As company cars are newer, operate more diesel engines, but are also larger, the fuel efficiency is slightly worse than that of private cars. Company cars seem to drive longer distances for commuting than the national average of private cars. Together, this might result in a net $1-7 \%$ increase of all fuel use of passenger cars in the Netherlands. This indicates that there is potential to reduce energy consumption of company cars and a need for policies aimed at improving energy efficiency of company cars.
\end{abstract}

(c) 2008 Elsevier Ltd. All rights reserved.

\section{Introduction}

Most, if not all, recent scenario studies show that in the next decades energy-efficiency improvement is the key option to mitigate greenhouse gas emissions, and that a considerable potential exists in any sector and economy. However, realization of this potential is subject to various barriers. Many studies have demonstrated the existence of market barriers for energyefficiency improvement (IPCC, 2001; DeCanio, 1993, 1994; Koomey et al., 1996; Sorrel et al., 2004), of which some are market failures, i.e. barriers that may lead to increased (energy) costs and hence a sub-optimization. One of the market failures is the so-called the principal-agent problem (Howarth et al., 2000). The principal-agent problem arises from asymmetric information, uncertainties and risks in the relationship between a principal and an agent. In this market failure, the stakeholders have split incentives that may lead to inefficiencies, i.e. the principal (e.g. tenant) has the interest to keep the energy costs of a home or office low as he/she pays the energy bills for the property, while the agent (e.g. the property owner) has a different incentive, i.e. keep investments as low as possible at a given rental income (IEA, 2007).

\footnotetext{
* Corresponding author at: Copernicus Institute, Utrecht University, Heidelberglaan 2, 3584 CS Utrecht, The Netherlands. Tel.: +31302537689; fax: +31302537601 .

E-mail address: E.worrell@uu.nl (E. Worrell).
}

In the context of this research, the principal-agent problem is a combination of two cases of split incentives, one concerning usage (demand for energy services) and the other concerning the technical efficiency of the end-use device. The principal-agent problem can be categorized according to the two-by-two matrix as given in Table 1, which classifies the technology according to the user's ability to choose the technology and the user's responsibility for paying associated energy costs.

Similarly, the principal-agent problem does play a role in the market of leased company cars. We examine a specific example of the principal-agent problem that is hypothesized to exist in fleets of vehicles owned by organizations/companies and operated by individuals who do not pay the full cost of ownership and use, including fuel use. The hypothesis is that since individual operators are not responsible for either vehicle selection, and operation, which both affect fuel economy, the principal (fleet owner or payer of fuel bills) would like to minimize fuel costs, but the agent (vehicle operator) may have no incentive to conserve fuel.

In the Netherlands, company lease cars are often provided to employees as an attractive co-benefit besides salary. The offer of a lease car is based on an employee's salary and work description; if an employee has to travel or has a high position, he or she might be offered a lease car. The car can be used for both professional and private use, while fuel costs are often paid for by the company. Often a domestic fuel card or one that can be used across Europe is provided with the car. This structure results in a situation where employees operating a company car have no 
Table 1

Principal-agent classification of energy end users

\begin{tabular}{|c|c|c|}
\hline & Chooses technology & $\begin{array}{l}\text { Does not choose } \\
\text { technology }\end{array}$ \\
\hline Pays energy bill & $\begin{array}{l}\text { Category 1: potentially no } \\
\text { principal-agent problem }\end{array}$ & $\begin{array}{l}\text { Category 2: efficiency } \\
\text { problem }\end{array}$ \\
\hline $\begin{array}{l}\text { Does not pay } \\
\text { energy bill }\end{array}$ & $\begin{array}{l}\text { Category 3: usage and efficiency } \\
\text { problem }\end{array}$ & $\begin{array}{l}\text { Category } 4: \text { usage } \\
\text { problem }\end{array}$ \\
\hline
\end{tabular}

financial incentive to limit fuel consumption and costs that are fully covered by the company. While the income tax system in the Netherlands taxes the use of a company lease cars to the extent it is used for private use, a company car is still considered an attractive co-benefit of a given job, especially as enforcement of the taxation is difficult. A share of the book value of the car is added to the taxable income of a household. This is done to reduce the advantage of company cars in terms of private use. If the mileage for private use remains below $500 \mathrm{~km} / \mathrm{yr}$ (to be proven with a detailed travel administration) no amount is added to the taxable income. If the mileage is above $500 \mathrm{~km} / \mathrm{yr}, 22 \%$ (Belastingdienst, 2005) of the book value of the car is added. This leads to an increased income tax of $€ 2000-2500$, depending on income level and an average book value of $€ 20,000$. The increased income tax is roughly equivalent to $11,000 \mathrm{~km}$ driving (or $€ 0.2 / \mathrm{km}$ ). Commuting is not considered private use of the company car by the Netherlands tax authorities. For some households it may therefore be more economic to use their private vehicle for private travel and stay below the $500 \mathrm{~km} / \mathrm{yr}$ threshold value for private travel with the company car. The share of households staying below $500 \mathrm{~km} / \mathrm{yr}$ is however likely to be small. The average mileage for private use of company cars was found to be $8700 \mathrm{~km} / \mathrm{yr}$, so most company cars are expected to exceed the threshold. Only recently (2008) have the Netherlands tax authorities started to enforce the taxing of the private use of company lease cars through photosurveillance.

In this particular case study, categories 3 and 4 of the principal-agent problem are applicable (see Table 1). In the Netherlands, vehicle fuel costs of company cars are paid by companies but operated and sometimes selected by individuals with no motive to save fuel. Fig. 1 depicts the financial relationship between the actors for company lease cars.

Sometimes employees are allowed to choose their own car, sometimes from a number of given options, in which category 3 applies. In other cases, cars are selected by companies themselves, in which category 4 apply. Sometimes these companies have an entire car fleet of the same or a few types of vehicles. The share of company cars that is selected by employees (category 3 ) versus the share of cars selected by companies (category 4) is unknown. The principal-agent problem may have two effects:

1. company cars are larger, more powerful and less fuel efficient than driver-owned cars and

2. the distance travelled by company cars is higher than the distance by driver-owned cars, because of more private travel and/or higher travel distance for commuting (see discussion above).

In the analysis, we make a distinction between company cars, i.e. cars that are owned and financed by companies, and used by individuals employed by the company, and driver-owned cars, which are privately owned and operated by individuals (hereafter named private cars). There are two types of company cars. The first is leased cars that are owned by car lease companies.

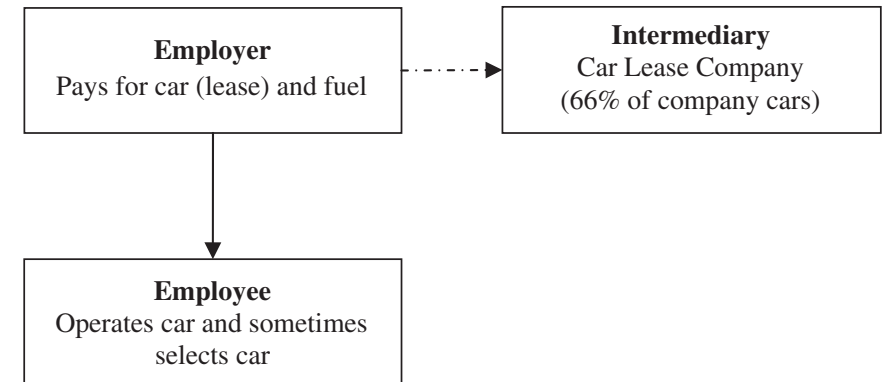

Fig. 1. Schematic representation of the relationship of various stakeholders in the analysis of company (lease) cars.

The second is cars administered and financed by companies themselves, i.e. company-owned fleets; we do not distinguish between the latter two groups, as we lack sufficient data to do so. This may affect the results.

This study was done as part of a larger study coordinated by the International Energy Agency (IEA) to study the extent of the principal-agent problem. The IEA study used case studies from many sectors in a number of countries (e.g. Australia, Japan, Netherlands, Norway, and the United States), which resulted in the book 'Mind the Gap' (IEA, 2007). In this article we report on a case study that was not included in the book due to the specificity of the case study. However, we believe that important lessons can be drawn from this case study, despite the specificity for the Netherlands, for the analysis of the principal-agent problem and for (energy) policy design.

In this paper we report on the methodology and data sources used. We discuss the energy use by the different types of cars, the magnitude of the principal-agent problem, as well as the net impact on energy use by passenger cars in the Netherlands. We end with a discussion of the results and conclusions with respect to the principal-agent problem, as well as policy implications.

\section{Approach and data sources}

In this paper we take three steps to estimate the impact of the principal-agent problem on energy use by passenger cars in the Netherlands (see also IEA, 2007):

1. Estimate the population of end-users affected by the principal-agent problem.

2. Estimate the energy consumption affected by the principalagent problem.

3. Estimate the impact of the principal-agent problem on energy use (or the potential energy savings if the barrier would be removed).

The energy used by passenger cars is affected by a number of factors, including fuel efficiency of the car and the distance travelled. The fuel efficiency of the car is affected by the type, weight, age, and fuel/technology (e.g. internal combustion, hybrid, diesel, gasoline). While fuel efficiency is also affected by the driving style (e.g. tyre pressure) there is insufficient data to include these in the analysis, and there is no reason to assume a difference in driving style due to the principal-agent problem observed.

Based on surveys and model calculations, there is a rich dataset in the Netherlands that allows to study a number of characteristics of the passenger car fleet in the Netherlands and to distinguish between privately owned cars and company lease cars. This allows addressing the three steps of the analysis. 
The data sets are provided by the Netherlands Central Bureau of Statistics (CBS) as well as the Netherlands Environmental Planning Bureau (MNP, formerly named RIVM). These datasets make it possible to analyze the following factors:

- fuel mix and fuel consumption

- mileage

- fuel intensity of car fleet and car weight

- total number of company cars

- fuel mix and consumption of company cars

- age distribution of cars

- car size

- travel purposes.

Also, in the Netherlands, the transport sector is one of the fastest growing energy using sectors and sources of greenhouse

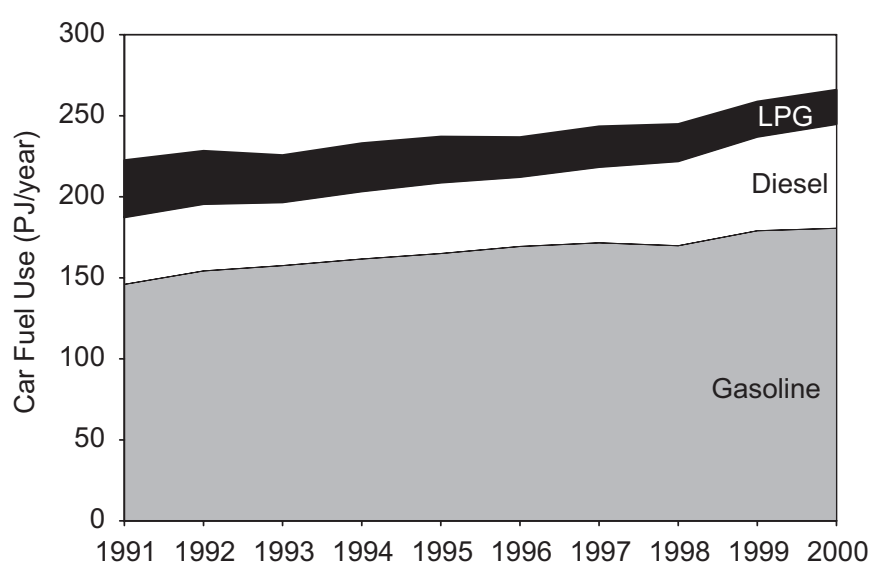

Fig. 2. Total fuel consumption by passenger cars in the Netherlands for the period 1991-2000 (in PJ/year). Source: CBS, 2005. gas emissions due to a rapid increase in fuel use by cars. The total fuel consumption by passenger cars has increased from 184 Peta Joule ( $10^{15}$ Joule, PJ) in 1980 to $260 \mathrm{PJ}$ in 2000 , and has not stopped growing since. In 2000, passenger cars consumed around $260 \mathrm{PJ}$ of fuel, or $8 \%$ of the total energy use in the Netherlands. The share of diesel in total fuel consumption has increased from 19\% in 1991 to $24 \%$ in 2000 , while the share of LPG in total fuel consumption has decreased from $16 \%$ in 1991 to $8 \%$ in 2000 . The 2000 passenger car fuel consumption consists of $24 \%$ diesel, $8 \%$ LPG and $68 \%$ gasoline. Fig. 2 shows the total fuel consumption by passenger cars in PJ for the period 1991-2000.

Fig. 3 depicts the development of transport service provided by passenger cars in the period 1992-2003, expressed as person-kilometres. The label "Driver" refers to the number of vehicle $\mathrm{km}$ (v.km) made by cars. The label "Passenger" refers to the distance travelled by passengers other than the driver in cars. The total is the number of passenger $\mathrm{km}$ (p.km) made by cars. The total transport distance in vehicle $\mathrm{km}$ has increased by $13 \%$ in the period $1992-2003$. For the period 2003-2020 an increase is expected of $34 \%$, from $146 \mathrm{p} . \mathrm{km}$ in 2003 to 172 billion p.km in 2010 and 195 billion p.km in 2020 (RIVM, 2000). The average number of car occupants has decreased slightly from 1.63 persons per car in 1992 to 1.57 persons per car in 2003.

Remarkable is that the fuel intensity has not decreased in the period 1992-2000, and that over the period 1980-1995 it actually increased (Farla and Blok, 2000), see Fig. 4. Engines and power trains have become more efficient, but this efficiency gain is compensated by an increased car weight, resulting in no net improvement in fuel efficiency. The average weight of new cars has increased from around $1050 \mathrm{~kg}$ in 1996 to around $1200 \mathrm{~kg}$ in 2004. The average weight of cars in the current car fleet is around $1080 \mathrm{~kg}$. In 1996 this was $963 \mathrm{~kg}$ (Wilmink et al., 2002). This is an increase of $12 \%$. The share of new cars per category of car weight is shown in Fig. 5. The share of new cars with a weight above $1150 \mathrm{~kg}$ has increased from 30\% in 1996 to $60 \%$ in 2004. Moreover, engine power has risen faster than car weight to increase acceleration,

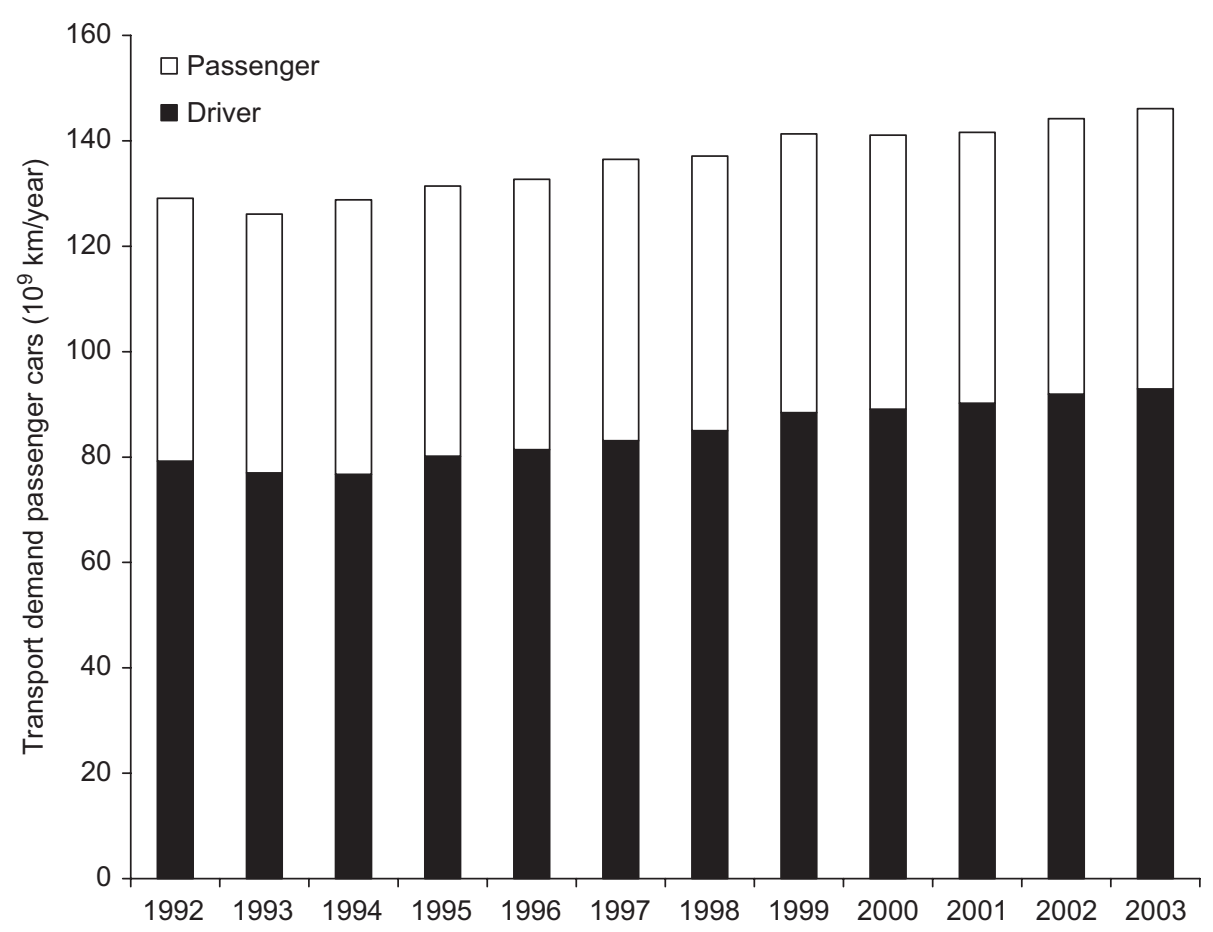

Fig. 3. Transport volume of passenger cars in the Netherlands for the period 1992-2003, expressed as $10^{9}$ person km/year. Source: CBS, 2005 . 


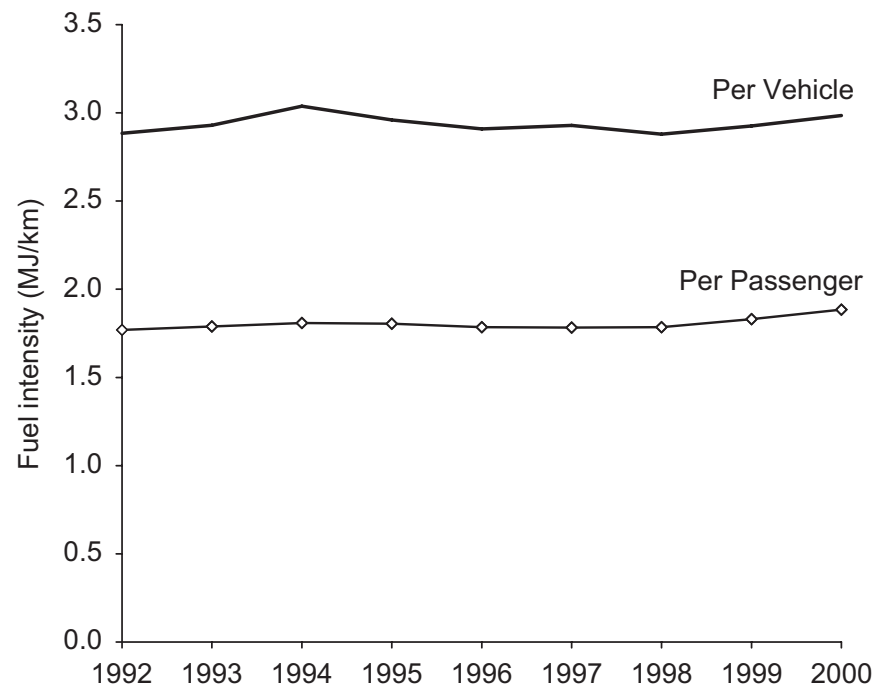

Fig. 4. Average fuel intensity of passenger cars in the Netherlands, expressed per vehicle $\mathrm{km}$ and passenger $\mathrm{km}$ in MJ/km Source: CBS, 2005.

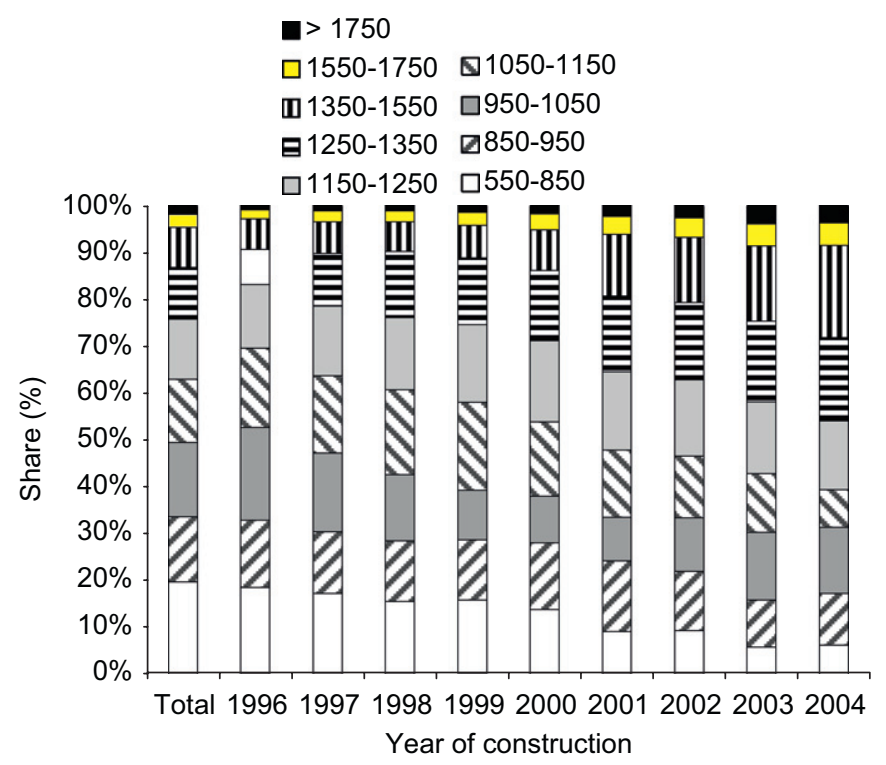

Fig. 5. Distribution of car weight $(\mathrm{kg})$ in the Netherlands by year of manufacture Source: CBS, 2005.

which further reduces engine efficiency as part-load use of the engine increases.

\section{Population affected by the principal-agent problem}

In this section we assess the population of the passenger car fleet, and assess the part of the fleet affected by the principal-agent problem. We also analyze the characteristics of the overall fleet of passenger cars and those specifically of company cars, and the use of the car (business use versus private and commuting use). Understanding the characteristics and the use of the cars is important to correctly estimate the energy consumption affected by the principal-agent problem (Step 2).

Between 1995 and 2005, the total number of cars increased by $24 \%$. The number of company cars has increased by $41 \%$ (from 548,000 to 771,531 cars). The share of company cars in the overall car fleet increased from 10\% in 1995 to $11 \%$ in 2005. The increase in the number of company cars was especially large in the period $1995-2002$, from 548,000 to 787,994 cars. In the period 2002-2005 the absolute number of company cars has remained equal at around 770,000 cars. The total number of cars increased by $4 \%$ in this period. The share of company cars in the car fleet decreased slightly from $11.7 \%$ in 2002 to $11.0 \%$ in 2005. Fig. 6 shows the total number of cars in the Netherlands in the period 1995-2005, divided in company cars and private cars. For the period 1996-1998 no data was available.

Company cars that are owned by lease companies number to 509,000 in 2004 (VNA, 2005). This corresponds to $7.2 \%$ of the total car fleet. The largest lease companies in the Netherlands in 2004 are LeasePlan Nederland NV, ING Car Lease, Athlon Car Lease and DaimlerChrysler Services BV (VNA, 2005).

\subsection{Vehicle fuel mix}

Company cars consume more often diesel than gasoline, and also the share of LPG as fuel of choice is for company cars larger than for private cars. Of the company cars, $47 \%$ consume diesel, $10 \%$ consume LPG and 43\% consume petrol in 2002 (Wilmink et al., 2002). For private cars these shares are $10 \%$ diesel, $86 \%$ petrol and 4\% LPG. Fig. 7 depicts the breakdown of private cars and company cars by fuel type in 2002 .

\subsection{Vehicle age distribution}

The age distributions of company lease and private cars are also interesting, as company cars are generally younger. Fig. 8 shows that of the total car fleet, $31 \%$ is more than 10 years old and $12 \%$ are more than 15 years old. Most company cars, $90 \%$, however are less than five years old. Company cars are most bought new, and sold on to the second had market after a few years. Fig. 8 shows the number of cars by year of manufacture at the beginning of 2004.

\subsection{Vehicle size}

The share of small cars (e.g. Fiant Punto) is 32\% for private cars. For company cars this is only $12 \%$. The share of small mediumsized cars (e.g. Volkswagen Golf) is $31 \%$ for private cars and $26 \%$ for company cars. For large medium-sized cars (e.g. Toyota Avensis) the share for company cars is 34\% and for private vehicles $22 \%$. The share of large cars (e.g. BMW 5 series) is $12 \%$ for company cars and $8 \%$ for private vehicles. For multi-purpose vehicles (MPVs) (e.g. Chrysler Voyager) the share for company cars is $10 \%$ and for private cars $3.5 \%$.

The top 10 of most newly registered leased cars in 2004 is Renault, Volkswagen, Peugeot, Opel, Volvo, Ford, Toyota, BMW, Audi and Citroen (VNA, 2005). The top 10 of most sold car brands in the Netherlands in 2004 is Opel, Volkswagen, Ford, Renault, Peugeot, Toyota, Fiat, Citroën, Nissan and Volvo (CBS, 2005). Fig. 9 depicts the size of private vehicles and company cars divided in five categories in 2002.

\subsection{Vehicle use}

The total travelled distance by passenger cars in the Netherlands was 92.9 billion v.km in 2003 (see Fig. 3). In 2001, 22\% of the total travelled distance by passenger cars is done by company cars and $78 \%$ is done by private cars (Wilmink et al., 2002). However, as shown above, company cars represent only $11 \%$ of the overall car fleet. This demonstrates that company cars on average drive nearly twice as much per year than private cars. The annual 


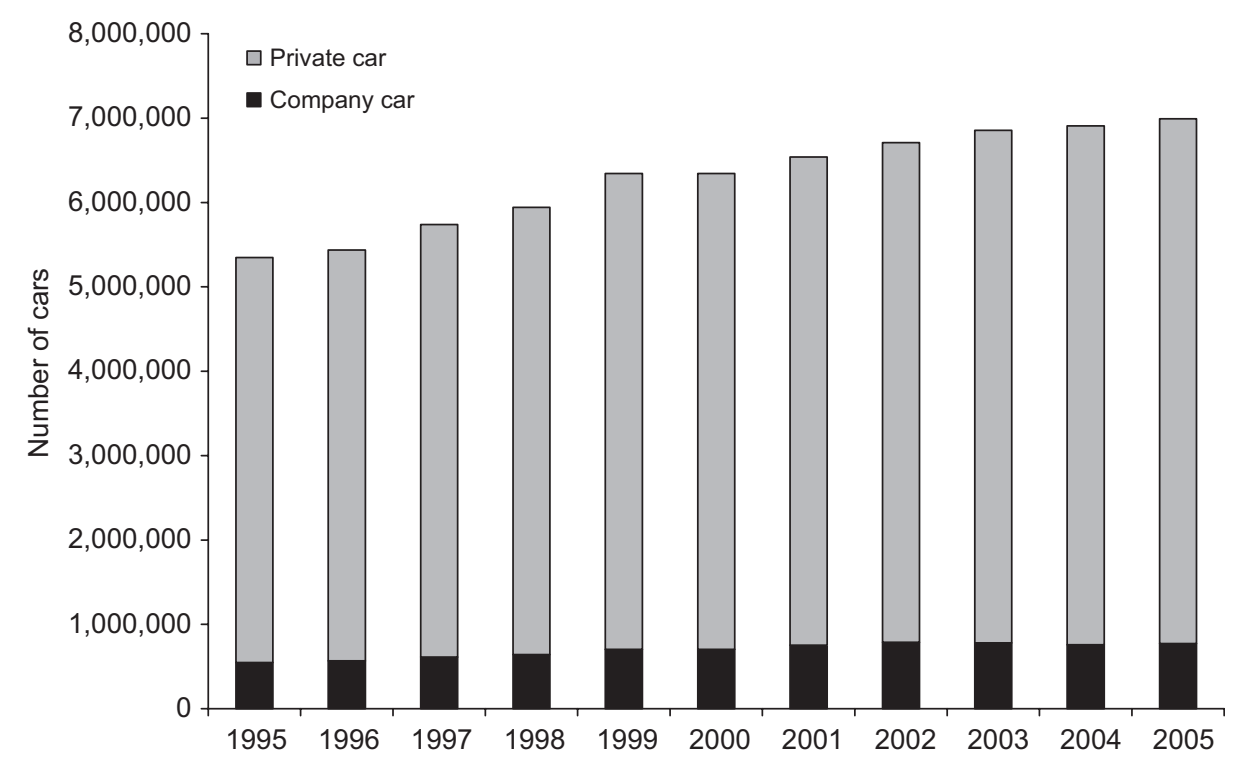

Fig. 6. Number of passenger cars in the Netherlands, subdivided in private and company cars. Source: CBS, 2005.

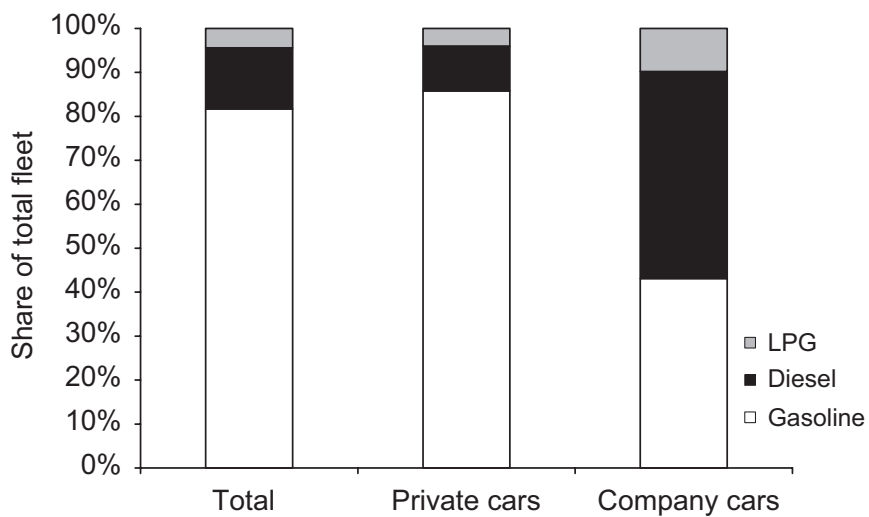

Fig. 7. Distribution of fuel mix by category of passenger cars in the Netherlands in 2002. Data sources: Wilmink et al., 2002 and CBS, 2005.

mileage of company cars is around $90 \%$ higher than the mileage of private cars. Fig. 10 shows the annual mileage for the period 1995-2001 for the company and driver-owned cars.

In 2001, the average mileage for company cars is $31,348 \mathrm{~km}$ and for private cars $16,435 \mathrm{~km}$. The mileage for company cars has decreased by $3.4 \%$ in the period $1995-2001$. Fig. 11 shows the breakdown of travel distance by purpose in terms of commute, business and private travel. Especially a difference is visible for commute and business travel.

The mileage for private use is nearly the same for private cars and company cars. Since 1995 the use of company cars for commuting has increased slightly from 11,500 to $13,000 \mathrm{~km} / \mathrm{yr}$ (Wilmink et al., 2002). The use of company cars for business has decreased from 13,000 in 1995 to $10,000 \mathrm{~km} / \mathrm{yr}$ in 2001 . The private use of company cars has remained equal at around $8500 \mathrm{~km} / \mathrm{yr}$. The total mileage of private cars has remained equal at around $16,400 \mathrm{~km} / \mathrm{yr}$. The commuting travel for private cars has increased slightly from 5000 to $5500 \mathrm{~km} / \mathrm{yr}$ while the use for private use has decreased slightly from around 9250 to $8750 \mathrm{~km} / \mathrm{yr}$. The average commuting distance for company car owners and private car owners is given in Fig. 12.

While the average commuting distance for private car owners has remained equal, the average commuting distance for company

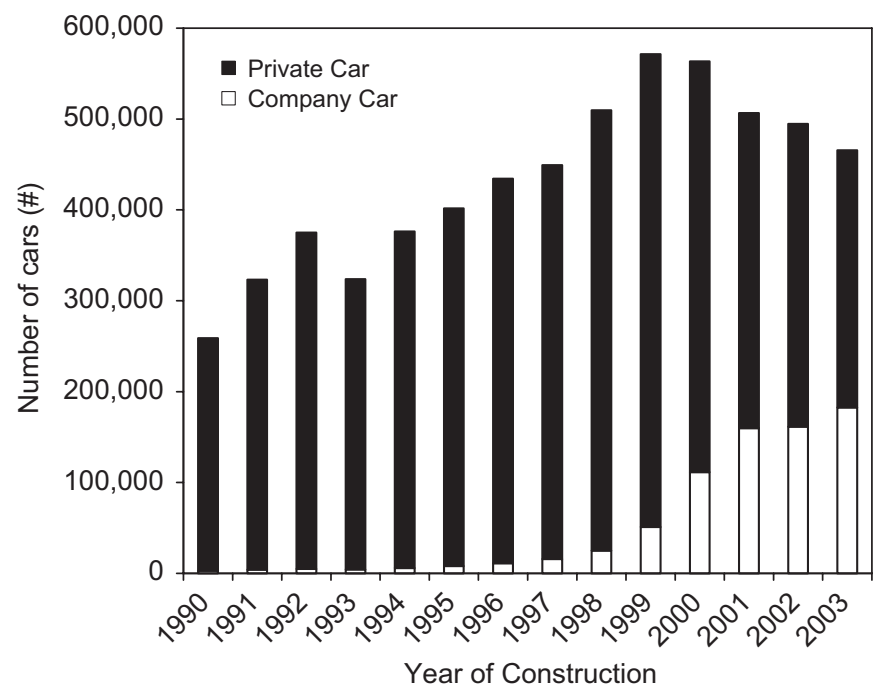

Fig. 8. Composition of the passenger car fleet in the Netherlands at the beginning of 2004, by year of manufacture. Source: CBS, 2005.

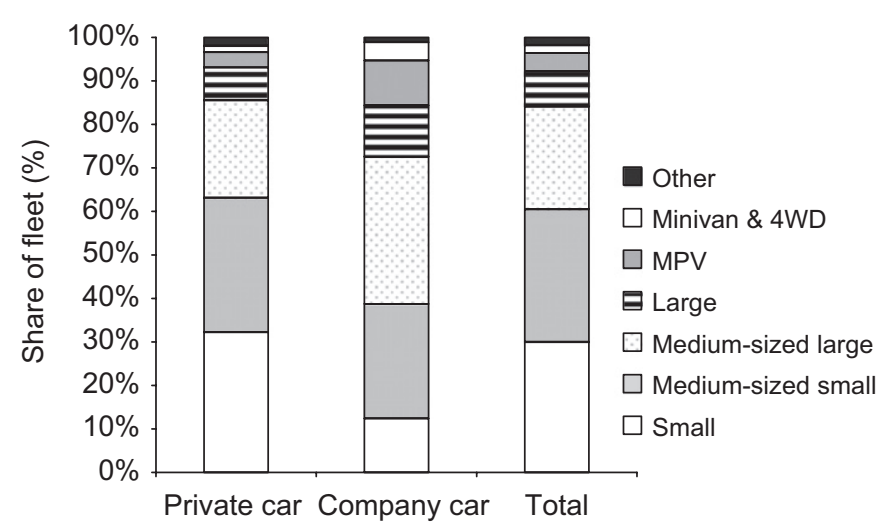

Fig. 9. Car size expressed in different categories for private and company passenger cars in the Netherlands. Source: Wilmink et al., 2002. 


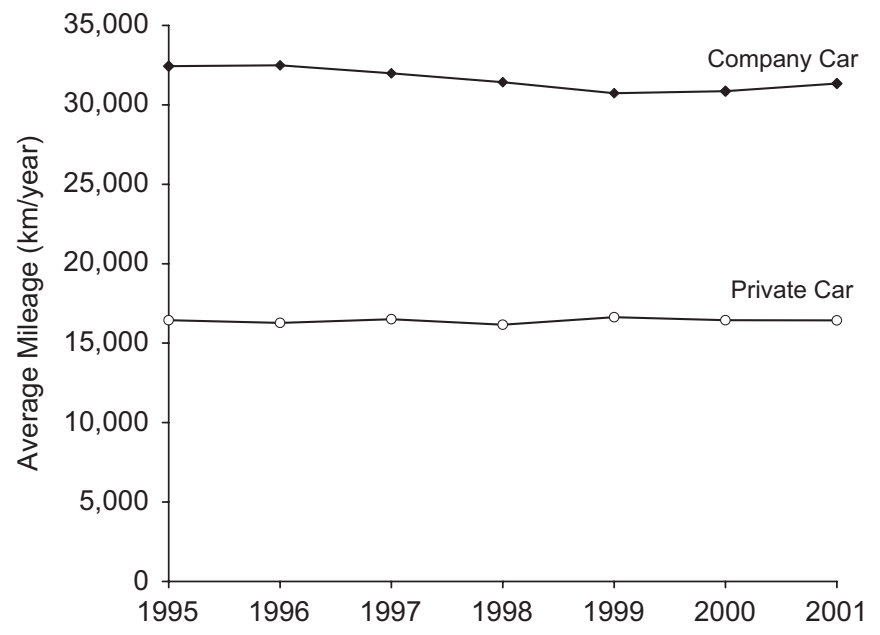

Fig. 10. Average annual mileage (expressed km/year) for company and private cars in the Netherlands for the period 1995-2001 Source: Wilmink et al., 2002.

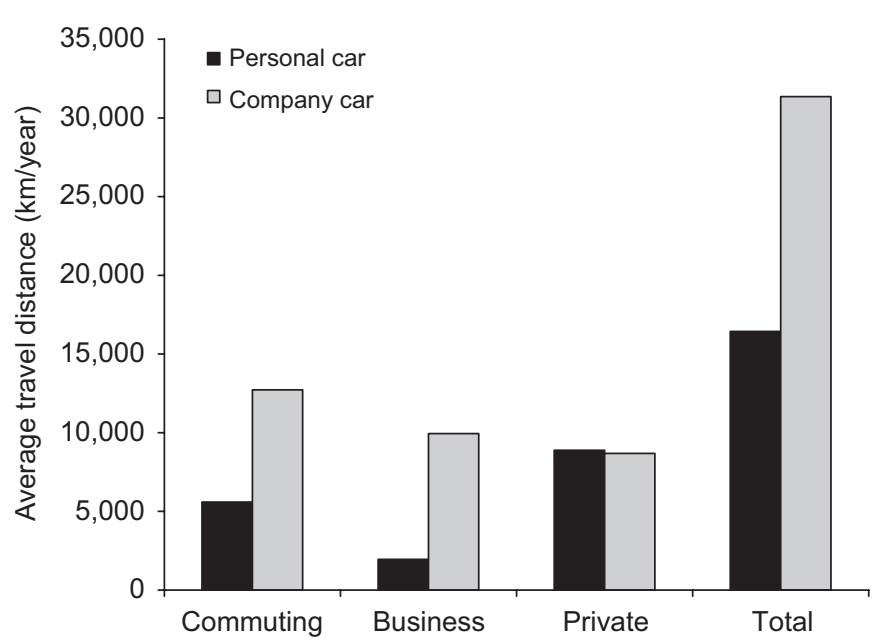

Fig. 11. Breakdown of average travel distance by trip purpose for private and company cars in the Netherlands in 2001 Source: Wilmink et al., 2002.

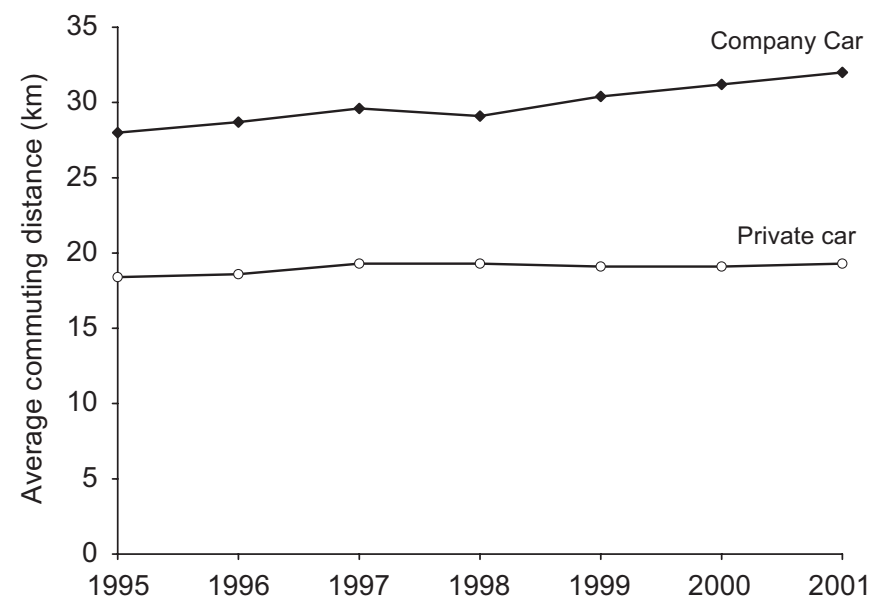

Fig. 12. Average commuting distance (expressed in $\mathrm{km}$ ) for company and private cars in the Netherlands. Source: Wilmink et al., 2002.

car owners has increased by 14\% in 2001 in comparison to 1995. The average commuting distance for company car owners is nearly 66\% higher in 2001 in comparison to the average

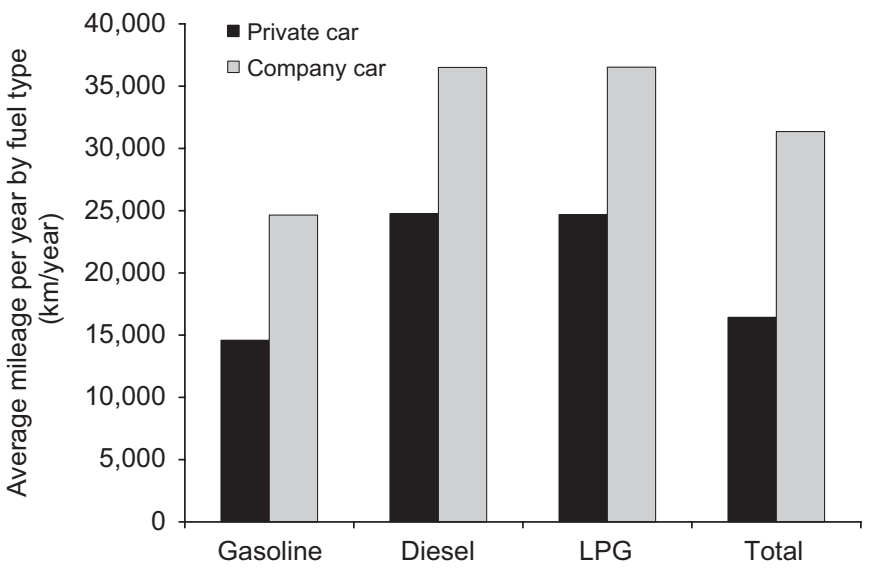

Fig. 13. Breakdown of mileage by car ownership category and fuel type in 2001 in the Netherlands. Source: Wilmink et al., 2002.

commuting distance for private car owners. Fig. 13 shows the annual mileage by fuel type. Diesel and LPG cars have the highest average mileage; around $36,500 \mathrm{~km} / \mathrm{yr}$ for company cars and around $25,000 \mathrm{~km} / \mathrm{yr}$ for private cars. Petrol cars have an average mileage of $24,500 \mathrm{~km} / \mathrm{yr}$ for company cars and $14,500 \mathrm{~km} / \mathrm{yr}$ for private cars.

In summary, considerable differences exist in the characteristics of the average car fleet and company (lease) car fleet. The characteristics influence the energy efficiency of the company car fleet in a positive sense, i.e. on average newer cars and a larger share of diesel cars that are more efficient, and in negative sense, i.e. company cars are larger and heavier. Interestingly, annual distance driven of company cars is found to be nearly twice the mileage for private cars; $31,348 \mathrm{~km}$ in comparison to $16,435 \mathrm{~km}$. Not surprisingly, business travel of company cars was found to be approximately 5 times larger $(\sim 10,000 \mathrm{~km} /$ year $)$ than that of the average fleet of driver-owned vehicles ( $\sim 2000 \mathrm{~km} / \mathrm{year})$. However, also the average annual commuting distance was found to be larger for company cars; $12.700 \mathrm{~km}$ in comparison to $5600 \mathrm{~km}$ for driver-owned cars. It was found that the mileage driven for private purposes is equal for company cars and private cars; around $9000 \mathrm{~km}$. The latter two effects are important to estimate the share of the energy use affected by the principal-agent problem and the net impact of the principal-agent problem.

\section{Estimating the impact of the principal-agent problem}

In this section we will first estimate the share of the energy consumption affected by the principal-agent problem, followed by the estimated net impact of the problem. We will (1) estimate the increased consumption of energy that is caused by the larger average size of company cars. Also we will look at (2) the effect of decreasing the commuting distance by company cars to the average commuting distance by private cars.

Table 2 shows the share of the total travel distance by passenger cars by fuel source. This is based on the data of Figs. 7 and 13 . As can be seen, the share of $\mathrm{km}$ travelled by diesel cars is larger (23\%) than the share of diesel cars in the total number of cars (14\%).

Table 3 shows the average fuel consumption for new standard cars by fuel source. The fuel efficiency for diesel cars is found to be approximately $20 \%$ better than the fuel efficiency of petrol cars.

The figures are derived from VROM (2005) and are typical figures for standard driving conditions. In practice, the energy consumption depends on driving style, congestion and infrastructure, e.g. share of travel on highways and urban roads, 
Table 2

Share of total travel distance (billion v.km) by fuel type

\begin{tabular}{lllr}
\hline & Petrol & Diesel & LPG \\
\hline Private cars (\%) & 78 & 16 & 6 \\
Company cars (\%) & 34 & 55 & 11 \\
Total (\%) & 69 & 23 & 7 \\
\hline
\end{tabular}

Table 3

Fuel consumption for new standard cars in $\mathrm{MJ} / \mathrm{v} . \mathrm{km}$

\begin{tabular}{llll}
\hline & Petrol & Diesel & LPG \\
\hline Small & 2.0 & 1.7 & 1.9 \\
Medium-sized small & 2.4 & 1.9 & 2.2 \\
Medium-sized large & 2.7 & 2.1 & 2.5 \\
Large & 3.0 & 2.4 & 2.7 \\
MPV & 3.3 & 2.6 & 3.0 \\
Minivan and 4WD & 3.3 & 3.0 & 3.0 \\
Other & 2.7 & 2.4 & 2.5 \\
\hline
\end{tabular}

Sources: VROM (2005) and OECD/IEA (2004).

number of traffic lights, roundabouts. The figures are only used relatively, in order to calculate the difference in fuel consumption between company cars and passenger cars. This assumes that there are no differences in e.g. driving styles between company cars and private cars. Although company cars are generally larger, the specific fuel consumption $(2.34 \mathrm{MJ} / \mathrm{v}-\mathrm{km})$ for new company cars is slightly lower than that of new private cars $(2.38 \mathrm{MJ} / \mathrm{v}-\mathrm{km})$. This is caused by the fact that the share of diesel cars is much higher in company cars. In this analysis we assume that the relative difference in fuel consumption for new private and company cars is the same as for all private and company cars. This is based on the fact that the fuel intensity for cars has remained equal in the period 1992-2000.

Table 4 shows the results for the calculation of (1) the extra energy consumption that is needed because company cars are larger than passenger cars and (2) the effect of decreasing the commuting distance by company cars to the average commuting distance by private cars.

The fuel consumption on a per km basis for company cars is slightly lower than the fuel consumption for private cars. The reason is that company cars more often consume diesel fuel than gasoline. $47 \%$ of the company cars consume diesel in comparison to $10 \%$ of the private cars in 2005 . Diesel cars are currently more energy efficient than gasoline cars. This effect is largely compensated by the fact that company cars are larger; $60 \%$ of the company cars can be referred to as large cars in comparison to $35 \%$ of private cars. If the average size of company cars is the same as the average size of private cars the energy savings amount to $4 \mathrm{PJ}$ or $1.5 \%$ of the total energy consumption of passenger cars.

The average annual mileage for company cars is $31,348 \mathrm{~km}$ in comparison to $16,435 \mathrm{~km}$ for private cars. The breakdown of the mileage for 2001 shows that the travel distance for private purposes of company cars is roughly equal to the distance for private cars; around $8800 \mathrm{~km} /$ year. The travel distance for commuting is much larger for company cars: 12,717 in comparison to $5598 \mathrm{~km} /$ year for private cars. Also, not surprisingly, the travel distance for business purposes is much higher 9949 versus $1952 \mathrm{~km} /$ year. In this chapter we calculated the extra energy consumption needed for the higher commuting distance. This corresponds to $16 \mathrm{PJ}$ or $6 \%$ of the total energy consumption for passenger cars.
Table 4

Estimating the overall impact of the principal-agent barrier on energy use by passenger cars in the Netherlands and the contributing factors

\begin{tabular}{|c|c|c|c|}
\hline & & Value & Unit \\
\hline \multirow[t]{3}{*}{1.} & $\begin{array}{l}\text { Average fuel consumption by } \\
\text { passenger cars }\end{array}$ & 2.98 & $\mathrm{MJ} / \mathrm{v} . \mathrm{km}$ \\
\hline & $\begin{array}{l}\text { Average fuel consumption company } \\
\text { cars }\end{array}$ & 2.94 & $\mathrm{MJ} / \mathrm{v} . \mathrm{km}$ \\
\hline & $\begin{array}{l}\text { Average fuel consumption private } \\
\text { cars }\end{array}$ & 2.99 & $\mathrm{MJ} / \mathrm{v} . \mathrm{km}$ \\
\hline \multirow[t]{3}{*}{2.} & Transport by passenger car & 93 & $10^{9}$ v.km \\
\hline & Transport by company car & 20 & $10^{9} \mathrm{v} . \mathrm{km}$ \\
\hline & Transport by private car & 73 & $10^{9} \mathrm{v} . \mathrm{km}$ \\
\hline \multirow[t]{3}{*}{3.} & $\begin{array}{l}\text { Energy consumption by passenger } \\
\text { cars }\end{array}$ & 277 & PJ/year \\
\hline & Energy consumption company cars & 59 & $\mathrm{PJ} /$ year \\
\hline & Energy consumption private cars & 218 & $\mathrm{PJ} /$ year \\
\hline \multicolumn{4}{|c|}{ Energy savings potential } \\
\hline \multicolumn{2}{|c|}{$\begin{array}{l}\text { Reducing average size of company cars to } \\
\text { average size of private cars }\end{array}$} & 4 & PJ/year \\
\hline \multicolumn{2}{|c|}{$\begin{array}{l}\text { Reducing commuting distance company cars to } \\
\text { average commuting distance of private cars }\end{array}$} & 16 & PJ/year \\
\hline \multicolumn{2}{|c|}{ Combining both measures } & 19 & $\mathrm{PJ} /$ year \\
\hline
\end{tabular}

Table 5

Principal-agent classification of end users

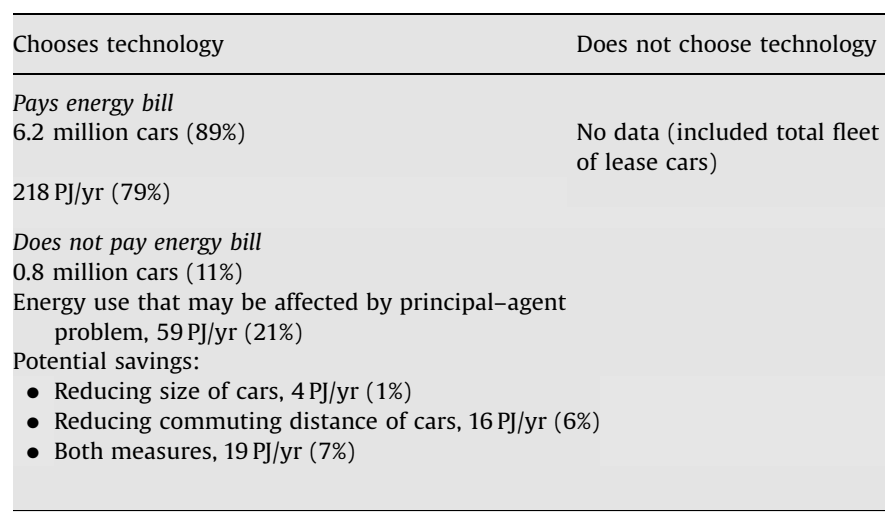

Table 4 shows that the largest potential for energy savings is present with reducing the commuting distance for company car owners. The possible reduction could result in a reduced energy consumption by $16 \mathrm{PJ} /$ year. Reducing the average size of company cars to that of driver-owned vehicles could result in a reduction of $4 \mathrm{PJ} /$ year. The total reduction when combining the two measures would be $19 \mathrm{PJ} /$ year. This corresponds to $7 \%$ of the total fuel consumption of passenger cars and to $32 \%$ of fuel consumption by company cars.

Our analysis has shown that the principal-agent problem might affect almost 800,000 cars, or $11 \%$ of the total fleet of passenger cars in the Netherlands, while it may affect $21 \%$ of the energy use by passenger cars in the Netherlands (see Table 5).

The analysis has also shown that removing this barrier to energy-efficiency improvement could lead to fuel savings between $1 \%$ and $7 \%$ of the total energy used by passenger cars in the Netherlands. The savings are due to a reduction in the size and weight of the car (1\%) and a potential reduction in commuting distance (6\%). The latter effect may be harder to realize, but the 
increased energy use may be an (indirect) long-term impact of the principal-agent problem. Removing the barrier may hence only be realized in the longer term.

\section{Discussion and implications}

Our calculations merely show what the potential energy savings are when the size and commuting travel of company cars is the same as for private cars. It is unknown whether the higher commuting distance and larger size of company cars is the result of solely the principal-agent problem. Other factors may affect the commuting distance and choice of vehicle. For example, company cars may be larger for representative reasons or safety concerns and unrelated to the principal-agent problem.

In order to determine the exact size of the principal-agent problem we need to know the fuel efficiency and the mileage for commuting and private travel of company cars would be when the vehicle and fuel costs would not be paid by the employer. This, however, cannot be discerned from the data available for this study. Looking in more detail at the underlying factors that may influence fuel consumption of company cars is outside of the scope of this study. This study merely shows the sensitivity of the company car sector to the principal-agent problem, and gives an indication of the possible size of the problem. This will require more study.

Furthermore, the commuting pattern may require more study. Various factors could contribute to the larger commuting distance, e.g. distance to the office, or travel to multiple destinations, other than the office (e.g. commercial travellers or service engineers). The available data to this study does not allow analyzing this pattern in more detail.

We were not able to distinguish between lease cars and company fleets as the data did not allow this. This may result in different estimates of the potential impact of the principal-agent problem in this case study.

This study does not address any indirect or secondary impacts other than those discussed above. A secondary impact may be that the larger and heavier lease cars end up in the used car market after the end of the lease. Of all new cars purchased in the Netherlands, nearly $40 \%$ are company cars. Most company lease cars are leased for a period of 3-4 years, and then sold off to the second hand market. As company cars are generally larger and heavier, this may mean that the overall car fleet in the Netherlands may move to higher overall weight and size, resulting in additional fuel use. The net impact is the result of similar factors as discussed in this analysis, as well as the efficiency of the car displaced. This is hard to estimate, and is excluded from the analysis.

Hence, this paper provides a first indication of the potential size of the principal-agent barrier in the case of leas cars in the Netherlands. As discussed, above more data on company fleet versus leas cars, commuting patterns, and impacts of sales of lease cars to the second-hand market (i.e. impact on total passenger car fleet over time).

The study demonstrates that there might be a pervasive principal-agent problem with respect to company passenger cars that may have a significant impact on the energy consumption of the sector. It may even have secondary impacts (e.g. commuting distance, composition of car fleet) that may have a long-lasting impact on energy use. There are important policy lessons to be learned from this. This study and other case studies (IEA, 2007) demonstrate the pervasive nature of the principal-agent problem in many sectors, and the overall impact it has on energy use and attempts for energy-efficiency improvement. Only tailored policies can help to remove the barriers, as blanket measures as increasing fuel prices may not directly affect the responsible stakeholders.

Starting in 2008, the Netherlands government has not only started to improve the surveillance on the use of company cars for private use, it has also changed the tax status of fuel-efficient lease cars (using the European energy labels for cars). The latter have been made more attractive for leasing, as the addition to income tax for fuel-efficient cars has been strongly reduced from $22 \%$ to $14 \%$. Fuel-efficient cars are those cars that have a European A-label. It may be interesting to repeat this study in a few years to study the impact of these policies on the composition of the company car fleet and energy use.

\section{Conclusions and recommendations}

In total $11 \%$ of the passenger car fleet in the Netherlands can be classified as company cars, which consume in total $21 \%$ of the total energy consumption by passenger cars. This relatively large share is a result of the longer travel distance of company cars in comparison to passenger cars, and larger company cars than private cars.

While the exact magnitude of the principal-agent problem is hard to estimate, we estimate that roughly $20 \%$ of the passenger car energy use in the Netherlands is affected by the principal-agent problem. The net impact of the barrier is estimated at a potential net increase in the energy use of passenger cars by $1-7 \%$.

Together this indicates that there may be a need and potential for reducing energy consumption of company cars and a need for policies aimed at improving energy-efficiency of company cars. In 2008, the Netherlands government has introduced a revised tax system for company cars, with much lower taxes for fuel efficient cars. It is expected that this will affect the choice of new lease cars for more efficient models. A repetition of this study in a few years may be able to demonstrate the impact of this policy change.

This study (and the larger study in other sectors) demonstrates the pervasive nature of the principal-agent problem in energy efficiency. However, the case studies have only focused on a number of sectors and countries. It is likely that these problems are an important factor hampering the impact of energy policies to improve energy efficiency and reduce related greenhouse gas and air pollutant emissions. Further and more systematic analysis of the principal-agent problem is recommended, to help improve the design of efficient and economic policy instruments.

\section{Acknowledgments}

This study was part of a larger study coordinated by the International Energy Agency (IEA) to study the extent of the principal-agent problem. The work reported on in this paper was funded by the Ministry of Economic Affairs of the Netherlands. We want to thank the ministry and the colleagues that participated in the research team for their support, review, and feedback for this study. We also thank two anonymous reviewers for their helpful comments. Any remaining errors, despite their efforts, are the responsibility of the authors. This paper does not necessarily reflect the views of the IEA, the Ministry of Economic Affairs, or the government of the Netherlands.

\section{References}

Belastingdienst, 2005. Auto van de zaak. The Hague, the Netherlands. <http:// www.belastingdienst.nl/buitenland/buitenland-05.html $>$.

CBS, 2005. Statline. Centraal Bureau voor de Statistiek (CBS), Voorburg/Heerlen, the Netherlands $\langle$ http://statline.cbs.nl $\rangle$. 
DeCanio, S., 1993. Barriers within firms to energy-efficiency investments. Energy Policy 21, 906-914.

DeCanio, 1994. Agency and control problems in us corporations: the case of energy-efficient investment projects. Journal of Economics of Business 1, $105-122$.

Farla, J.C.M., Blok, K., 2000. The use of physical indicators for the monitoring of energy intensity developments in the Netherlands, 1980-1995. Energy 25, 609-638.

Howarth, R., Haddad, B., Paton, B., 2000. The economics of energy efficiency: insights from voluntary participation programs. Energy Policy 28, 477-486.

IEA, 2007. Mind the Gap, Quantifying Principal-Agent Problems in Energy Efficiency. International Energy Agency, Paris, France.

IPCC, 2001. Climate Change 2001: Mitigation. A Report of Working Group III of the Intergovernmental Panel on Climate Change. Cambridge University Press, Cambridge, UK

Koomey, J., Sanstad, A.H., Shown, L.J., 1996. Energy-efficient lighting: market data, market imperfections and policy success. Contemporary Economic Policy 14, 98-111.
OECD/IEA, 2004. Oil Crises \& Climate Challenges-30 Years of Energy Use in IEA Countries. Paris, France.

RIVM, 2000. Verkeer en Vervoer in de Nationale Milieuverkenning 5. National Institute of Public Health and the Environment (RIVM), Bilthoven, the Netherlands 〈http://www.rivm.nl/bibliotheek/rapporten/408129014.pdf $\rangle$.

Sorrel, S., O’Malley, E., Schleich, J., Scott, S. (Eds.), 2004. The Economics of Energy Efficiency. Edward Elgar, Cheltenham, UK.

VNA, 2005. Vehicle Leasing Market. Annual Figures for 2004. Association of Dutch Vehicle Leasing Companies (VNA), Bunnik, the Netherlands.

VROM, 2005. Energielabel Personenauto's. Netherlands Ministry of Housing Spatial Planning and the Environment (VROM), The Hague, the Netherlands (Data received 6 September 2005) <www.vrom.nl/get.asp?file = docs/ publicaties $/$ milieu4195.pdf\&dn $=4195 \& b=$ vrom $\rangle$.

Wilmink, I.R., Eijkelenbergh, P.L.C., Korver, W., Droppert-Zilver, M.N., 2002. De zakenautorijder aan het begin van de $21 \mathrm{e}$ eeuw. Commissioned by Vereniging Nederlandse Autoleasemaatschappijen (VNA). TNO Inro, Delft, the Netherlands <http://www.vna-lease.nl/DataRoot/docs/De\%20zakenautorijder\%20aan\%20 het\%20begin\%20van\%20de\%2021e\%20eeuw.pdf $>$. 